\title{
RANCANG BANGUN SISTEM PENILAIAN KINERJA PEMERINTAH DAERAH
}

\author{
Eddy Samsoleh ${ }^{1}$, Hani Rubiani ${ }^{2}$ \\ ${ }^{1,2}$ Program Studi Teknik Elektro, Fakultas Teknik, Universitas Muhammadiyah Tasikmalaya \\ Email: ${ }^{1}$ samsoleh@gmail.com, ${ }^{2}$ hani.rubiani@umtas.ac.id
}

\begin{abstract}
ABSTRAK
Kinerja pegawai negeri sipil di lingkungan pemerintah daerah selalu mendapat sorotan dari masyarakat. Terkait dengan penilaian kinerja pegawai negeri sipil, pemerintah sudah mengeluarkan beberapa kebijakan. yaitu Peraturan Pemerintah No. 46 Tahun 2011 dan Peraturan Pemerintah No. 30 tahun 2019. Di dalam Peraturan Pemerintah ini, penilaian Kinerja PNS bertujuan untuk menjamin objektivitas pembinaan PNS yang didasarkan pada sistem prestasi dan sistem karier. Sistem Informasi Kinerja PNS sebagai bagian dari system manajemen kinerja PNS merupakan sarana untuk merencanakan, mengumpulkan, mengolah, menganalisis, menyajikan, mendokumentasikan data penilaian kinerja PNS, dan bahan evaluasi kinerja. Maksud dan tujuan penelitian ini adalah merancang dan membangun system informasi penilaian kinerja pegawai atau disingkat dengan aplikasi e-kinerja yang dapat digunakan untuk memenuhi tanggung jawab undang-undang. Hasil implementasi kegiatan rancangan bangun aplikasi e-kinerja adalah berupa prototipe aplikasi e-kinerja yang siap digunakan.
\end{abstract}

Kata Kunci: Kinerja PNS, Sistem Manajemen, Sistem Informasi Kinerja PNS, e-kinerja.

\section{PENDAHULUAN}

\subsection{Latar Belakang}

Kinerja pegawai negeri sipil di lingkungan pemerintah daerah selalu mendapat sorotan dari masyarakat. Tidak sedikit masyarakat yang mempertanyakan mengenai kinerja pegawai negeri sipil dalam menjalankan tugasnya memberikan pelayanan kepada masyarakat. Pemerintah tentunya memahami hal ini dan karenanya sudah mengeluarkan berbagai kebijakan mengenai penilaian kinerja pegawai untuk memastikan terjadinya penilaian kinerja pegawai yang tepat dan obyektif.

Terkait dengan penilaian kinerja pegawai negeri sipil, pemerintah sudah mengeluarkan beberapa kebijakan. Kebijakan pertama yaitu Peraturan Pemerintah No. 46 Tahun 2011 mengenai penilaian prestasi kerja pegawai negeri sipil. Di dalam peraturan pemerintah ini dijelaskan mengenai kewajiban setiap pegawai untuk menyusun rencana kinerja pegawai yang disebut sebagai Sasaran Kinerja Pegawai (SKP) setiap tahun. SKP pegawai ini akan disusun oleh masing-masing pejabat penilai yang merupakan atasan dari pegawai. Di dalam peraturan pemerintah ini juga dijelaskan mengenai tata cara dan rumus perhitungan penilaian kinerja pegawai.

Kebijakan kedua yang dikeluarkan oleh pemerintah terkait penilaian kinerja pegawai negeri sipil adalah Peraturan Pemerintah No. 30 tahun 2019 tentang penilaian kinerja pegawai negeri sipil. Peraturan Pemerintah ini merupakan penjabaran dari Undangundang No. 5 tahun 2014 mengenai Aparatur Sipil Negara (ASN). Di dalam Peraturan Pemerintah ini, penilaian Kinerja PNS bertujuan untuk menjamin objektivitas pembinaan PNS yang didasarkan pada sistem prestasi dan sistem karier. Penilaian dilakukan berdasarkan perencanaan kinerja pada tingkat individu dan tingkat unit atau organisasi, dengan memperhatikan target, capaian, hasil, dan manfaat yang dicapai, serta perilaku PNS.

Penilaian Kinerja PNS sebagaimana dimaksud Peraturan Pemerintah (PP) Nomor 30 Tahun 2019 tentang Penilaian Kinerja Pegawai Negeri Sipil (PNS), dilaksanakan dalam suatu Sistem Manajemen Kinerja PNS yang terdiri atas:

1. Perencanaan kinerja;

2. Pelaksanaan, pemantauan kinerja, dan pembinaan kinerja;

3. Penilaian kinerja;

4. Tindak lanjut; dan

5. Sistem Informasi Kinerja PNS.

\subsection{Tinjuan Pustaka}

Basis data relasional diperlukan untuk mendapatkan sekumpulan schema relasi yang baik. Rancangan yang buruk akan mengakibatkan perulangan informasi dan tidak dapat menampilkan kembali informasi tertentu (Silberschatz, 2006).

Tujuan utama perancangan basis data adalah:

a. Menghindari kerangkapan data.

b. Menjamin bahwa kerelasian antar atribut dapat direpresentasikan.

c. Memberikan fasilitas pengecekan batasan integritas pada proses update

Menurut (Wellington, 2017) bagaimana membangun aplikasi web yang berguna dan aman menggunakan (Hypertext Preprocessor) PHP dan MySQL bersamasama. Ini juga memberikan dasar yang kuat untuk bahasa PHP dan menjelaskan cara mengatur dan menggunakan MySQL dan bagaimana menggunakan PHP untuk bekerja dengan basis data dan web server.

\subsection{Metodologi Penelitian}

Sistem Penilaian Kinerja Pemerintah Daerah adalah sistem untuk membantu penilaian prestasi kerja PNS 
di lingkungan pemerintah daerah. Secara umum penilaian prestasi kerja meliputi kegiatan-kegiatan:

1. Pemutakhiran data-data pegawai.

2. Penyusunan dan penetapan SKP.

3. Pengisian aktifitas kerja PNS.

4. Penilaian kerja PNS.

Berikut proses bisnis penilaian kinerja secara umum:

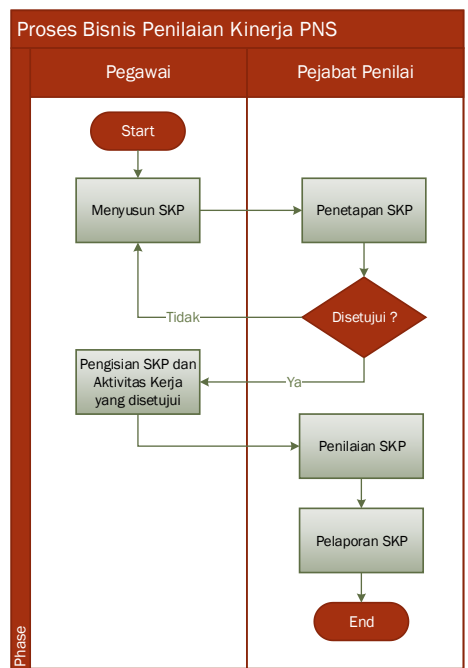

\section{Gambar 1. Proses Bisnis Penilaian Kinerja PNS}

Aplikasi e-kinerja dibangun untuk mengakomodasi kegiatan - kegiatan tersebut di atas supaya kegiatan kegiatan tersebut dapat dijalankan dengan bantuan teknologi IT. Pada prakteknya aplikasi yang dibangun tidak cukup hanya memiliki kemampuan untuk melaksanakan kegiatan - kegiatan di atas. Diperlukan adanya berbagai inovasi sehingga aplikasi yang dibangun dapat beroperasi secara optimal dan bermanfaat.

Aplikasi e-kinerja yang dikembangkan akan semakin memudahkan pegawai untuk melakukan penyusunan SKP dan aktifitas kerja karena setiap PNS di SKPD akan dilibatkan dalam aplikasi E-Kinerja untuk melakukan kegiatan penyusunan SKP secara online. Selain itu, aplikasi E-Kinerja akan terintegrasi dengan perangkat daerah sehingga akan tercapai pengukuran penilaian prestasi kerja pegawai menjadi lebih baik. Berikut workflow aplikasi E-Kinerja Kota Bekasi yang akan dibangun:

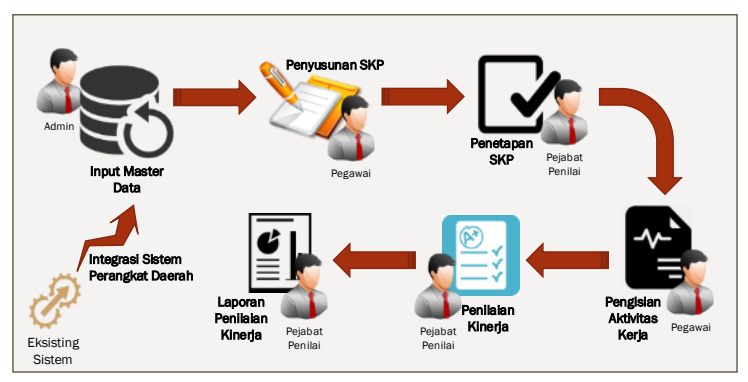

Gambar 2. Workflow Aplikasi E-Kinerja

Arsitektur sistem akan menggambarkan sistem secara umum, baik itu komponen - komponen pembentuk sistem maupun perilaku umum dari sistem. Berikut adalah arsitektur aplikasi E-Kinerja secara umum:

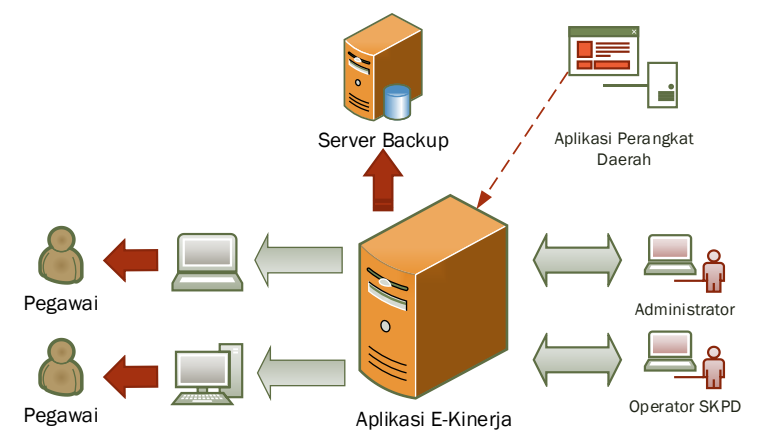

Gambar 3. Arsitektur Sistem Aplikasi E-Kinerja Kota Bekasi

Penjelasan arsitektur sistem aplikasi E-Kinerja Kota Bekasi adalah sebagai berikut:

1. Sistem yang dibangun adalah sistem dengan arsitektur client-server, dimana sistem secara umum terdiri bagian client dan bagian server. Bagian client adalah bagian yang akan diakses oleh pengguna, dimana melalui bagian client ini, pengguna dapat mengajukan berbagai request untuk mengakses data di dalam sistem. Bagian server selanjutnya akan memproses setiap request dari client.

2. Server terdiri dari dua bagian, yaitu server aplikasi sistem dan server backup. Server aplikasi adalah server tempat dimana aplikasi maupun data diinstall sehingga dapat melayani setiap request dari client. Adapun server backup adalah server untuk menyimpan backup yang dapat diaktifkan apabila server aplikasi mengalami gangguan. Dengan demikian ketersediaan sistem dapat secara berkesinambungan tersedia.

3. Aplikasi E-Kinerja akan terintegrasi dengan aplikasi perangkat daerah lainnya yang terkait dengan penilaian kinerja.

4. Sistem yang dibangun adalah sistem berbasis web. Artinya sistem akan dibangun dengan teknologi website dan diinstall di dalam server. Adapun pengguna/client dapat mengakses sistem melalui aplikasi web browser.

5. Di dalam sistem ada berbagai pengguna sesuai dengan peran dan kewenangannya. Setiap pengguna sistem hanya dapat mengakses bagian sistem hanya sesuai dengan peran dan kewenangannya.

\section{PEMBAHASAN}

Dalam pembahasan ini membahas entitas-entitas yang akan melakukan aktivitas di dalam system juga tentang use case aplikasi dalam E-Kinerja beserta definisi-definisinya. 


\subsection{Entitas yang Berperan dalam Pengelolaan Data}

Aplikasi e-kinerja melibatkan beberapa entitas yang akan berperan dalam proses pengelolaan data. Entitas-entitas tersebut adalah sebagai berikut:

Tabel 1. Entitas-entitas dalam e-kinerja

\begin{tabular}{|l|l|l|}
\hline No & \multicolumn{1}{|c|}{ Aktor } & \multicolumn{1}{c|}{ Deskripsi } \\
\hline 1 & $\begin{array}{l}\text { Administrator } \\
\text { Sistem }\end{array}$ & $\begin{array}{l}\text { Aktor yang diberikan otoritas } \\
\text { untuk semua fungsi - fungsi } \\
\text { pada Aplikasi E-Kinerja Kota } \\
\text { Bekasi }\end{array}$ \\
\hline 2 & $\begin{array}{l}\text { Operator } \\
\text { SKPD }\end{array}$ & $\begin{array}{l}\text { Aktor yang diberikan hak } \\
\text { akses untuk melakukan proses } \\
\text { review SKP dan menilai } \\
\text { laporan realisasi kinerja } \\
\text { pegawai yang berada dibawah } \\
\text { komandonya. }\end{array}$ \\
\hline 3 & Pegawai & $\begin{array}{l}\text { Aktor yang diberikan hak } \\
\text { akses untuk mengelola SKP } \\
\text { tahunan dan melakukan input } \\
\text { aktivitas kerja sebagai } \\
\text { realisasi dari SKP kepada } \\
\text { pejabat penilai. }\end{array}$ \\
\hline
\end{tabular}

Entitas-entitas tersebut akan melakukan berbagai aktivitas di dalam system. Berikut adalah gambaran aktivitas-aktivitas yang akan dilakukan oleh entitasentitas tersebut di dalam system.

\subsection{Use Case Aplikasi E-Kinerja Kota Bekasi}

Use case adalah sebuah kegiatan atau interaksi yang saling berkaitan antara aktor dan sistem. Atau secara umum, dapat diartikan sebagai sebuah teknik untuk yang dimanfaatkan untuk pengembangan perangkat lunak (software), guna mengetahui kebutuhan fungsional dari sistem tersebut.

\section{Tabel 2. Definisi Use Case Aplikasi E-Kinerja} Kota Bekasi

\begin{tabular}{|l|l|l|}
\hline $\begin{array}{c}\text { No. Use } \\
\text { Case }\end{array}$ & Use Case & \multicolumn{1}{c|}{ Deskripsi } \\
\hline Modul: Dashboard \\
\hline UC-1 & Log In & $\begin{array}{l}\text { Use case yang menangani } \\
\text { autentifikasi pengguna yang } \\
\text { ingin masuk kedalam sistem. }\end{array}$ \\
\hline UC-2 & $\begin{array}{l}\text { Akses } \\
\text { Dashboard }\end{array}$ & $\begin{array}{l}\text { Use case yang menampilkan } \\
\text { halaman dashboard / halaman } \\
\text { utama setelah pengguna login } \\
\text { kedalam aplikasi sesuai dengan } \\
\text { hak akses nya masing-masing. }\end{array}$ \\
\hline UC-3 & Log Out & $\begin{array}{l}\text { Use case yang menangani } \\
\text { autentifikasi pengguna yang } \\
\text { ingin keluar dari sistem. }\end{array}$ \\
\hline Modul: Referensi & $\begin{array}{l}\text { Kelola } \\
\text { Proporsi } \\
\text { Tunjangan }\end{array}$ & $\begin{array}{l}\text { Use case yang menangani } \\
\text { proses input data proporsi } \\
\text { tunjangan yang akan } \\
\text { digunakan pada aplikasi. }\end{array}$ \\
\hline UC-5 & $\begin{array}{l}\text { Kelola } \\
\text { Tunjangan } \\
\text { JFU }\end{array}$ & $\begin{array}{l}\text { Use case yang menangani } \\
\text { proses input data tunjangan } \\
\text { JFU yang akan digunakan pada } \\
\text { aplikasi. }\end{array}$ \\
\hline
\end{tabular}

\begin{tabular}{|c|c|c|}
\hline $\begin{array}{l}\text { No. Use } \\
\text { Case }\end{array}$ & Use Case & Deskripsi \\
\hline UC-6 & $\begin{array}{l}\text { Kelola } \\
\text { Nilai } \\
\text { Kreatifitas }\end{array}$ & $\begin{array}{l}\text { Use case yang menangani } \\
\text { proses input data nilai } \\
\text { kreatifitas yang akan } \\
\text { digunakan pada aplikasi. }\end{array}$ \\
\hline \multicolumn{3}{|c|}{ Modul: Sinkronisasi } \\
\hline UC-7 & $\begin{array}{l}\text { Sinkronisasi } \\
\text { Golongan } \\
\text { Ruang }\end{array}$ & $\begin{array}{l}\text { Use case yang menangani } \\
\text { proses sinkronisasi data } \\
\text { golongan ruang yang akan } \\
\text { digunakan pada aplikasi. }\end{array}$ \\
\hline UC-8 & $\begin{array}{l}\text { Sinkronisasi } \\
\text { Eselon }\end{array}$ & $\begin{array}{l}\text { Use case yang menangani } \\
\text { proses sinkronisasi data eselon } \\
\text { yang akan digunakan pada } \\
\text { aplikasi. }\end{array}$ \\
\hline UC-9 & $\begin{array}{l}\text { Sinkronisasi } \\
\text { Jenis } \\
\text { Jabatan }\end{array}$ & $\begin{array}{l}\text { Use case yang menangani } \\
\text { proses sinkronisasi data jenis } \\
\text { jabatan yang akan digunakan } \\
\text { pada aplikasi. }\end{array}$ \\
\hline UC-10 & $\begin{array}{l}\text { Sinkronisasi } \\
\text { Unit Kerja }\end{array}$ & $\begin{array}{l}\text { Use case yang menangani } \\
\text { proses sinkronisasi data unit } \\
\text { kerja yang akan digunakan } \\
\text { pada aplikasi. }\end{array}$ \\
\hline UC-11 & $\begin{array}{l}\text { Sinkronisasi } \\
\text { Jabatan JFT }\end{array}$ & $\begin{array}{l}\text { Use case yang menangani } \\
\text { proses sinkronisasi data jabatan } \\
\text { JFT yang akan digunakan pada } \\
\text { aplikasi. }\end{array}$ \\
\hline UC-12 & $\begin{array}{l}\text { Sinkronisasi } \\
\text { Jabatan JFU }\end{array}$ & $\begin{array}{l}\text { Use case yang menangani } \\
\text { proses sinkronisasi data jabatan } \\
\text { JFU yang akan digunakan pada } \\
\text { aplikasi. }\end{array}$ \\
\hline UC-13 & $\begin{array}{l}\text { Sinkronisasi } \\
\text { Status } \\
\text { Pegawai }\end{array}$ & $\begin{array}{l}\text { Use case yang menangani } \\
\text { proses sinkronisasi data status } \\
\text { pegawai yang akan digunakan } \\
\text { pada aplikasi. }\end{array}$ \\
\hline \multicolumn{3}{|c|}{ Modul: Data } \\
\hline UC-14 & $\begin{array}{l}\text { Kelola Data } \\
\text { PNS }\end{array}$ & $\begin{array}{l}\text { Use case yang menampilkan } \\
\text { data pegawai PNS. }\end{array}$ \\
\hline UC-15 & $\begin{array}{l}\text { Kelola Data } \\
\text { TKK }\end{array}$ & $\begin{array}{l}\text { Use case yang menampilkan } \\
\text { data pegawai TKK. }\end{array}$ \\
\hline \multicolumn{3}{|c|}{ Modul: Kontrak Kerja } \\
\hline UC-16 & $\begin{array}{l}\text { Kelola Data } \\
\text { SKP }\end{array}$ & $\begin{array}{l}\text { Use case yang menangani } \\
\text { proses input data SKP Tahunan } \\
\text { pada aplikasi. }\end{array}$ \\
\hline UC-17 & $\begin{array}{l}\text { Mapping } \\
\text { SKP }\end{array}$ & $\begin{array}{l}\text { Use case yang menangani } \\
\text { proses mapping data SKP } \\
\text { Tahunan yang sudah diinput } \\
\text { sebelumnya. }\end{array}$ \\
\hline UC-18 & $\begin{array}{l}\text { Approval } \\
\text { SKP }\end{array}$ & $\begin{array}{l}\text { Use case yang menangani } \\
\text { proses persetujuan data SKP } \\
\text { Tahunan yang telah diajukan. }\end{array}$ \\
\hline \multicolumn{3}{|c|}{ Modul: Aktivitas Kerja } \\
\hline UC-19 & $\begin{array}{l}\text { Kelola } \\
\text { Aktivitas } \\
\text { Harian }\end{array}$ & $\begin{array}{l}\text { Use case yang menangani } \\
\text { proses input aktivitas kerja } \\
\text { harian baik itu tugas pokok, } \\
\text { tugas tambahan, tugas } \\
\text { kreatifitas, atau kegiatan } \\
\text { harian. }\end{array}$ \\
\hline \multicolumn{3}{|c|}{ Modul: Penilaian Kerja } \\
\hline UC-20 & $\begin{array}{l}\text { Penilaian } \\
\text { Kinerja } \\
\text { Harian }\end{array}$ & $\begin{array}{l}\text { Use case yang menangani } \\
\text { proses penilaian kerja harian. }\end{array}$ \\
\hline UC-21 & $\begin{array}{l}\text { Penilaian } \\
\text { Kinerja } \\
\text { Bulanan } \\
\end{array}$ & $\begin{array}{l}\text { Use case yang menangani } \\
\text { proses penilaian kerja bulanan. }\end{array}$ \\
\hline
\end{tabular}




\section{IMPLEMENTASI}

Hasil implementasi kegiatan rancangan bangun aplikasi e-kinerja adalah berupa prototip aplikasi ekinerja yang siap digunakan. Berikut ini adalah penjelasan fitur-fitur system e-kinerja yang sudah dibangun.

1. Fitur pengelolaan data pegawai

Fitur pengelolaan data pegawai adalah fitur untuk mendapat setiap pegawai yang akan menggunakan aplikasi e-kinerja ini.

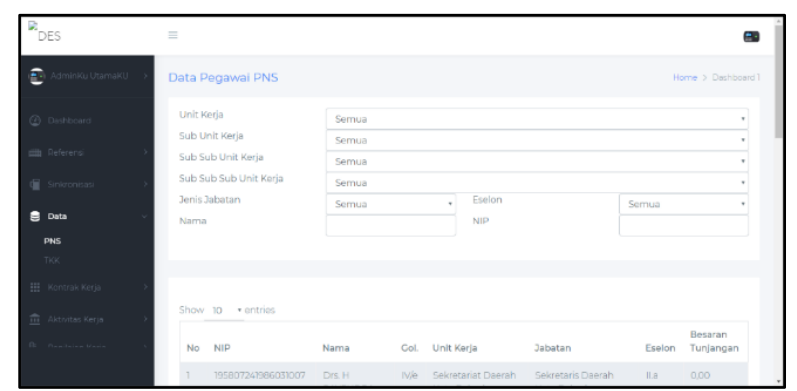

Gambar 4. Fitur Pengelolaan Data Pegawai

2. Fitur SKP

Fitur SKP adalah fitur yang digunakan oleh pegawai untuk memasukkan data SKP tahunannya. Berikut adalah gambaran bagaimana SKP diinputkan ke dalam sistem.

a. Akses menu SKP seperti digambarkan berikut ini.

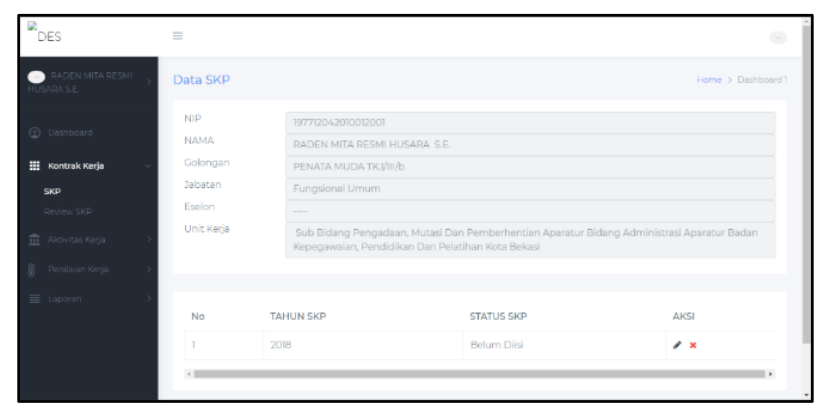

Gambar 5. Menu SKP

b. Untuk menambahkan data SKP, klik tombol Rincian SKP pada tabel:

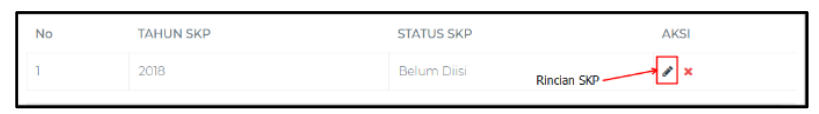

Gambar 6. Rincian SKP

c. Maka akan tampil form seperti berikut ini:

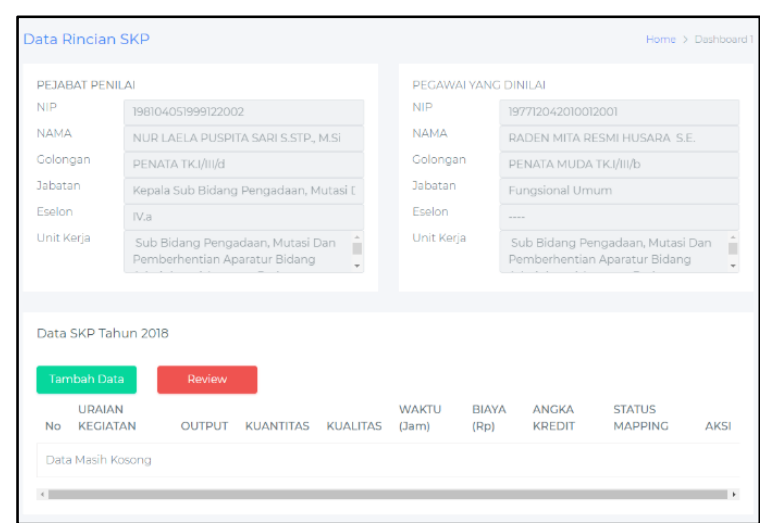

Gambar 7. Form Data Rincian SKP

d. Untuk menambahkan data SKP, klik tombol Tambah Data.

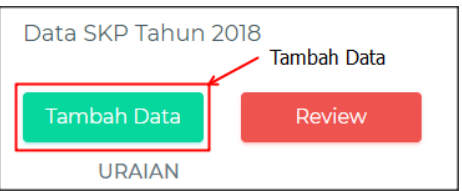

Gambar 8. Tambah Data SKP

e. Maka akan tampil Form seperti dibawah ini:

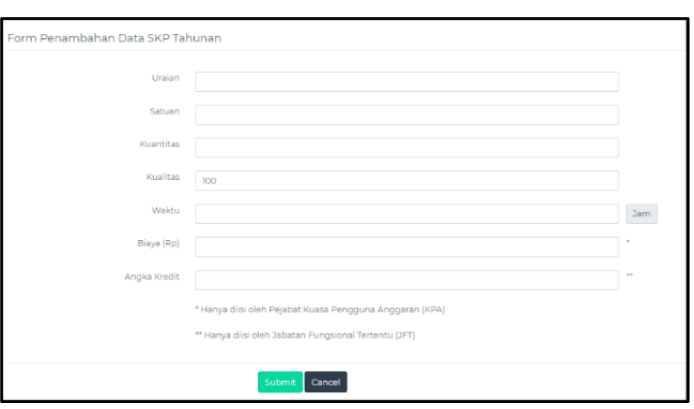

Gambar 9. Form Tambah Data SKP

f. Uraian Kegiatan yang baru ditambahkan akan tampil pada tabel Data Form SKP:

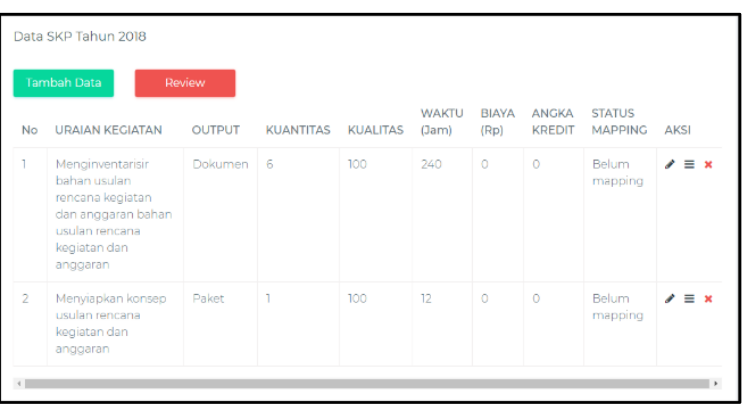

Gambar 10. Tabel Data Form SKP

g. Lakukan proses Tambah Data kembali hingga data SKP selesai diinput.

h. Selama proses input data SKP, status SKP akan berubah menjadi "Proses Pengisian":

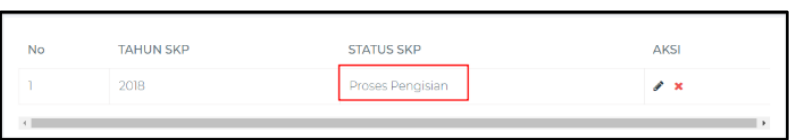

Gambar 11. Status SKP 
i. Setelah data SKP diinput, harus dilakukan proses mapping SKP. Uraian Kegiatan yang belum dimapping, status yang akan ditampilkan adalah "Belum Mapping":

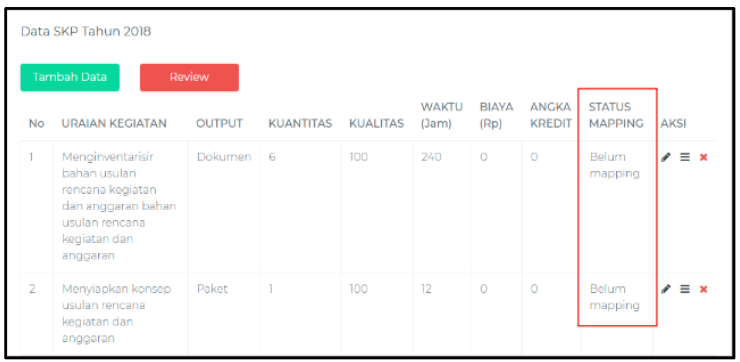

Gambar 12. Proses Mapping SKP

3. Fitur mapping SKP Pegawai

Untuk melakukan mapping data SKP, klik tombol Mapping di masing-masing data:

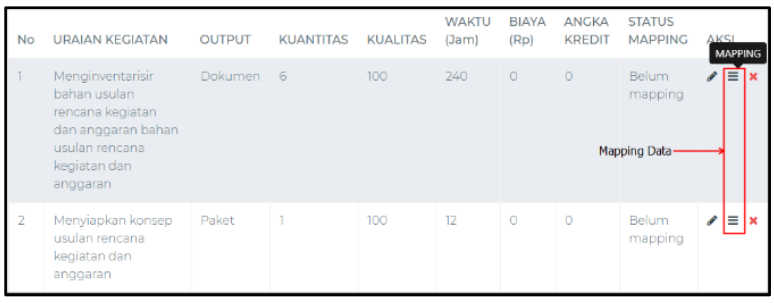

Gambar 13. Mapping Data SKP

a. Maka akan tampil form Input Mapping SKP seperti dibawah ini:

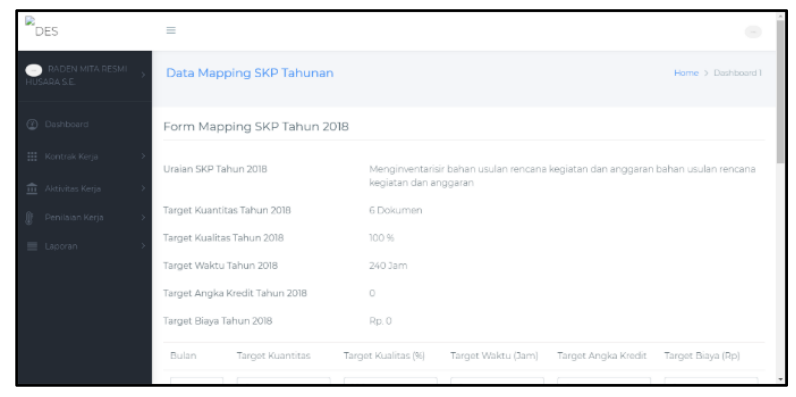

Gambar 14. Form Input Mapping SKP

b. Sistem akan menampilkan informasi data uraian kegiatan pada halaman Data Mapping SKP Tahunan seperti dibawah ini:

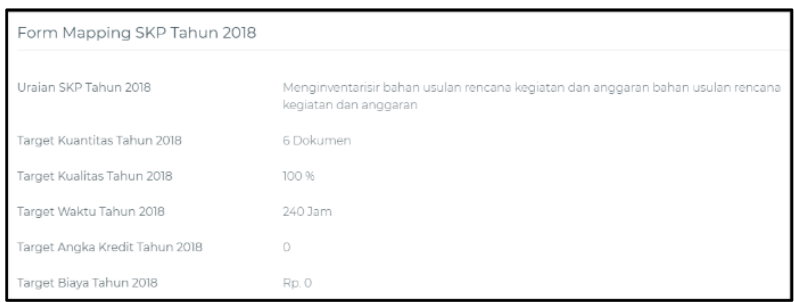

Gambar 15. Data Uraian Mapping SKP Tahunan

c. Input Target Kuantitas, Target Kualitas, Target Waktu, Target Angka Kredit, dan Target Biaya untuk setiap bulannya.

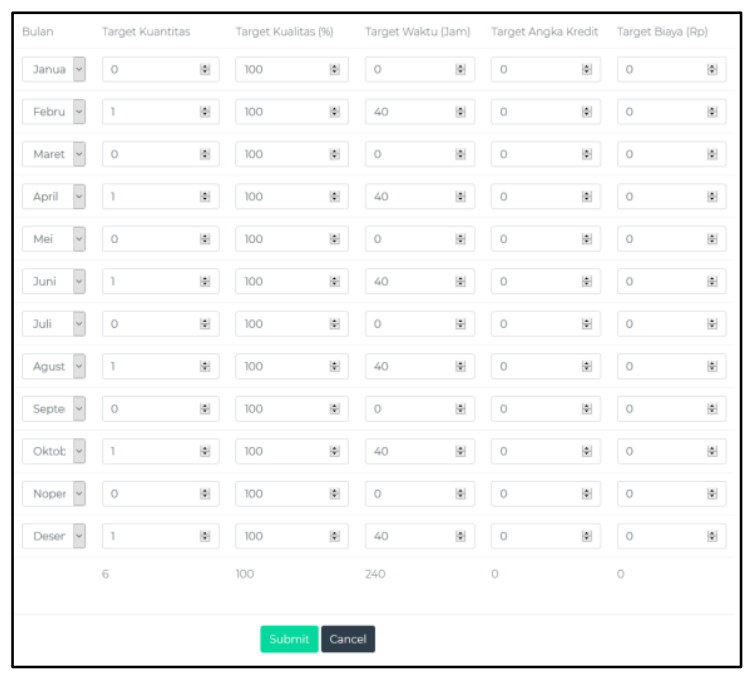

Gambar 16. Input Target Bulanan

d. Setelah mapping selesai, klik tombol Submit untuk menyimpan data.

4. Fitur Review SKP

Fitur ini digunakan oleh atasan pegawai untuk me-review pengajuan SKP pegawai. Tahapannya adalah sebagai berikut:

a. Untuk mengakses submenu Review SKP pilih menu Kontrak Kerja $\rightarrow$ Review SKP, dan akan muncul tampilan seperti pada gambar di bawah ini:

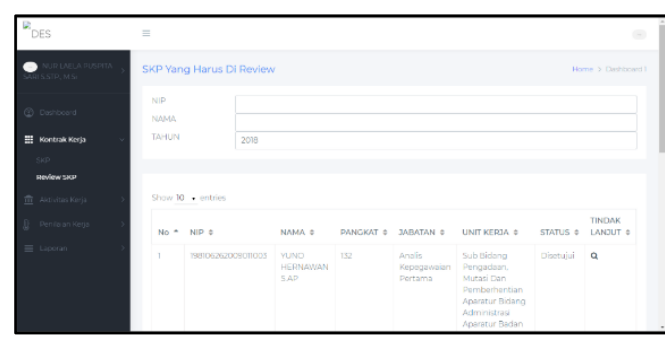

Gambar 17. Review SKP

b. Lakukan proses pencarian data SKP Yang Harus Di Review:

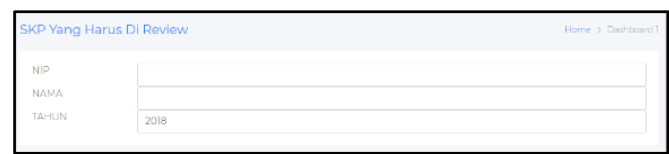

Gambar 18. Data Yang Harus di Review

c. Maka akan tampil hasil pencarian seperti berikut ini:

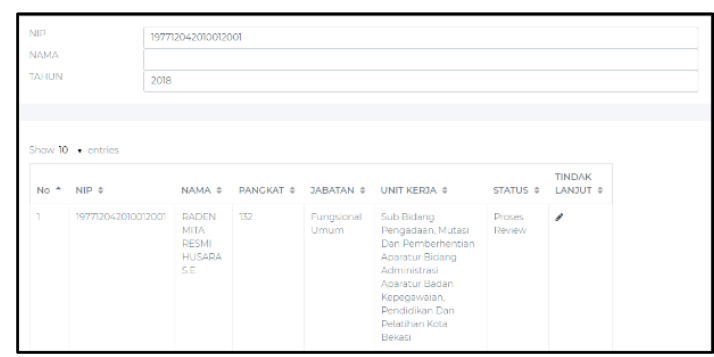

Gambar 19. Hasil Pencarian Data Review 
d. Pilih salah satu data untuk di Review dengan status "Proses Review", klik tombol pada kolom Tindak Lanjut di masing-masing data untuk melihat detail SKP sehingga akan keluar tampilan sebagai berikut:

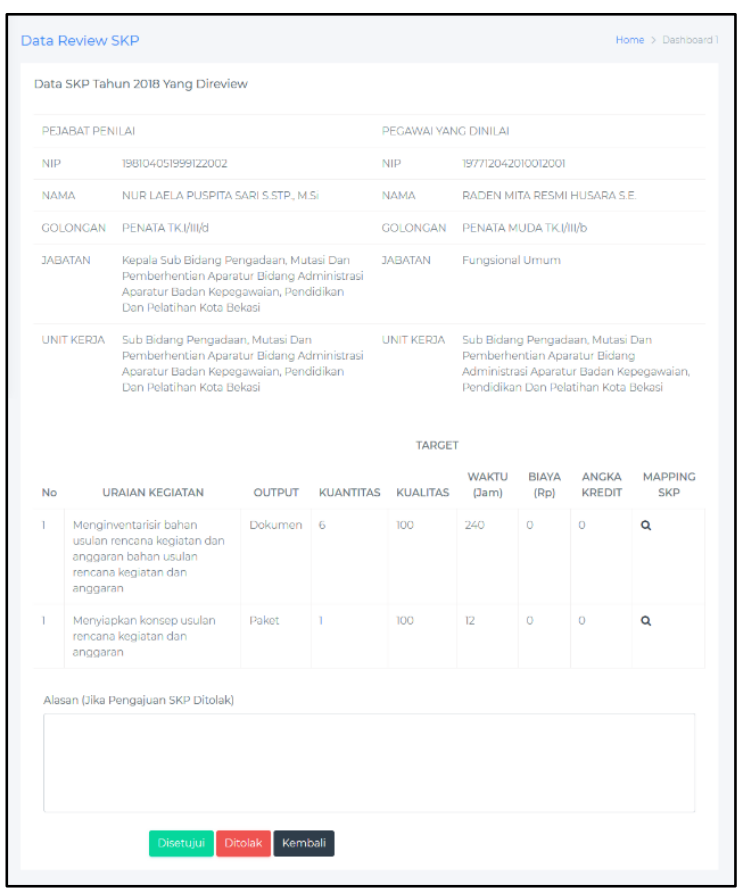

\section{Gambar 20. Data Review SKP}

e. Klik tombol disetujui jika akan menyetujui pengajuan SKP pegawai, atau klik ditolak jika pengajuan SKP ditolak oleh atasan.

5. Fitur aktivitas kerja

Fitur ini adalah fitur yang memfasilitasi pelaporan kegiatan harian oleh pegawai. Tahapan penggunaannya adalah sebagai berikut.

a. Untuk mengakses submenu Form Aktivitas Harian pilih menu Aktifitas Kerja $\rightarrow$ Form Aktivitas Harian, dan akan muncul tampilan seperti pada gambar di bawah ini:

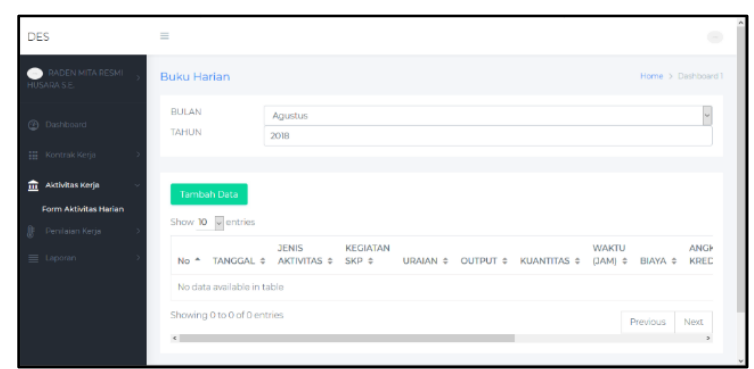

Gambar 21. Form Aktivitas Harian

b. Untuk menambah data aktivitas harian, klik tombol Tambah Data maka akan tampil form seperti berikut:

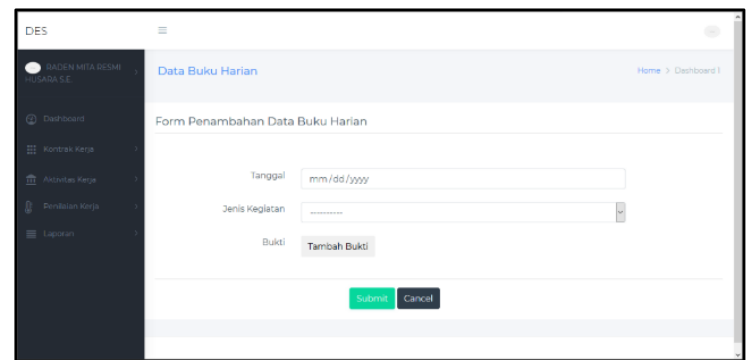

Gambar 22. Tambah Data Aktivitas Harian

1. Pilih Tanggal

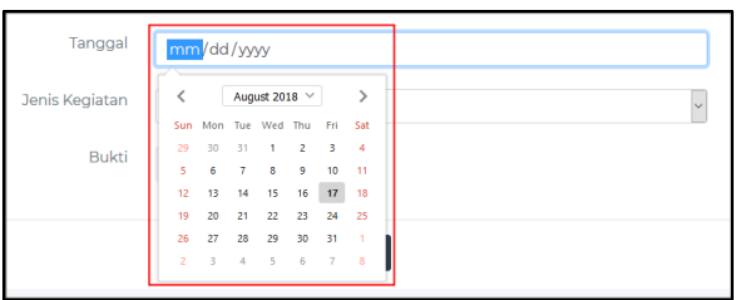

Gambar 23. Menu Pilih Tanggal

2. Pilih Jenis Kegiatan (Tugas Pokok/Tugas Tambahan / Tugas Sementara)

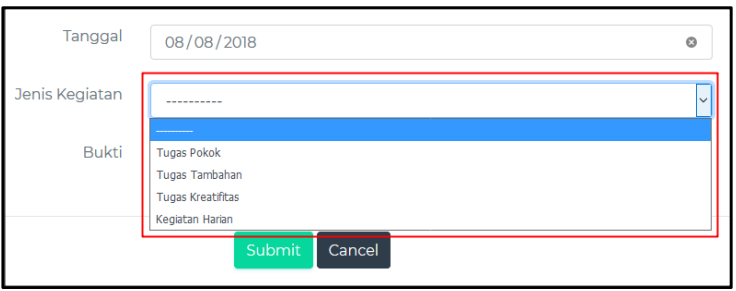

Gambar 24. Menu Pilih Kegiatan

3. Apabila memilih Tugas Pokok, maka akan tampil field isian seperti berikut ini:

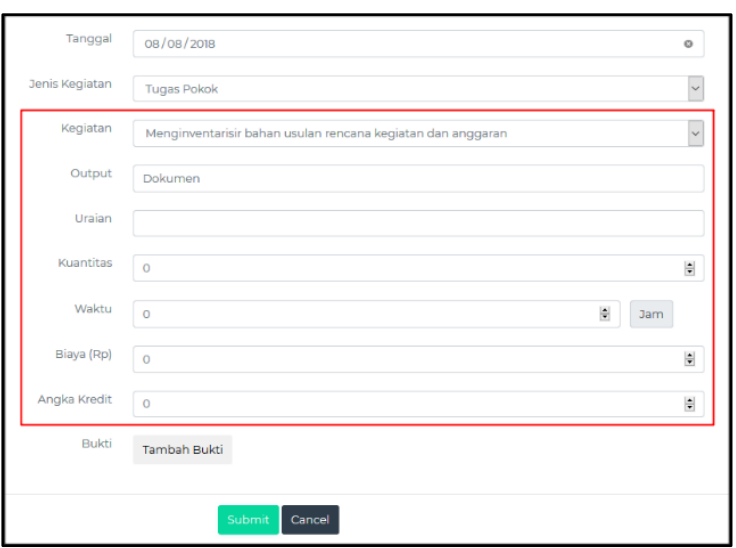

\section{Gambar 25. Menu Tugas Pokok}

4. Apabila memilih Tugas Tambahan, maka akan tampil field isian seperti berikut ini: 


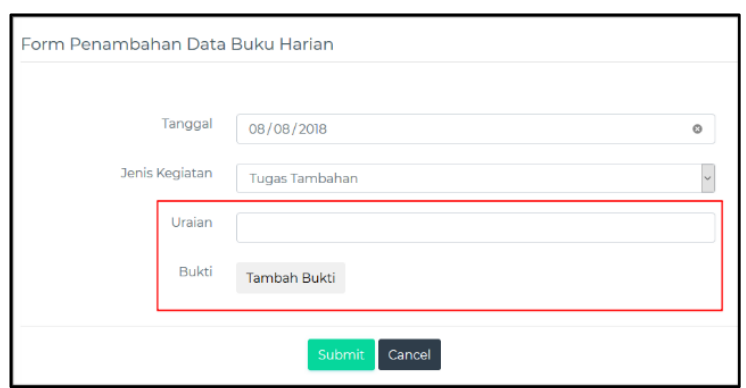

Gambar 26. Menu Tugas Tambahan

5. Apabila memilih Tugas Kreatifitas, maka akan tampil field isian seperti berikut ini:

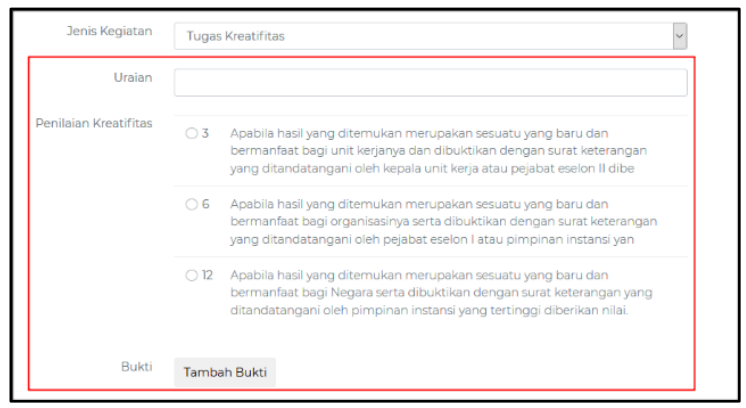

Gambar 27. Menu Tugas Kreatifitas

6. Kemudian klik tombol Submit untuk menambahkan data baru atau klik Cancel untuk membatalkan penambahan data baru.

7. Data yang baru ditambahkan akan tampil pada tabel Data Form Aktivitas Harian

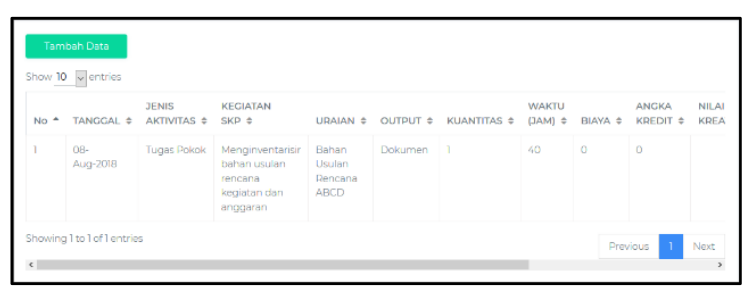

Gambar 28. Data Form Aktivitas Harian

6. Fitur Penilaian Kinerja

Fitur ini digunakan untuk melakukan pengisian nilai kinerja pegawai oleh masing-masing atasannya. Berikut tahapannya:

a. Untuk mengakses submenu Form Penilaian Kinerja Bulanan pilih menu Penilaian Kerja $\rightarrow$ Form Penilaian Kinerja Bulanan, maka akan tampil gambar seperti dibawah ini

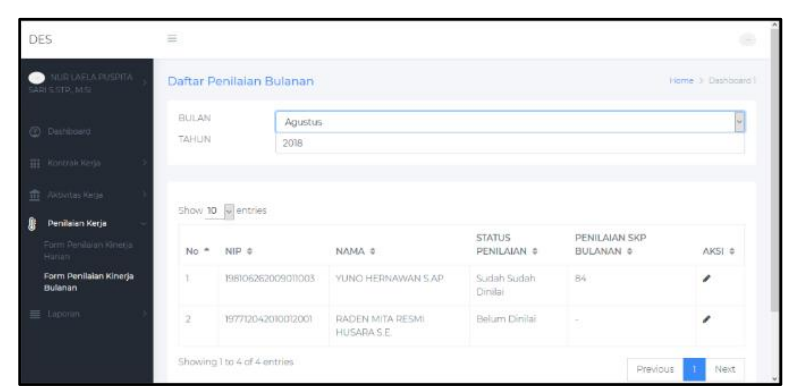

Gambar 29. Fitur Penilaian Kinerja b. Untuk input data penilaian, pilih tombol berikut di masing-masing data yang akan di nilai

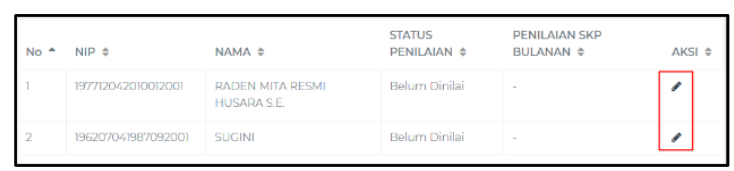

\section{Gambar 30. Input Data Penilaian}

c. Akan tampil form penilaian seperti berikut :

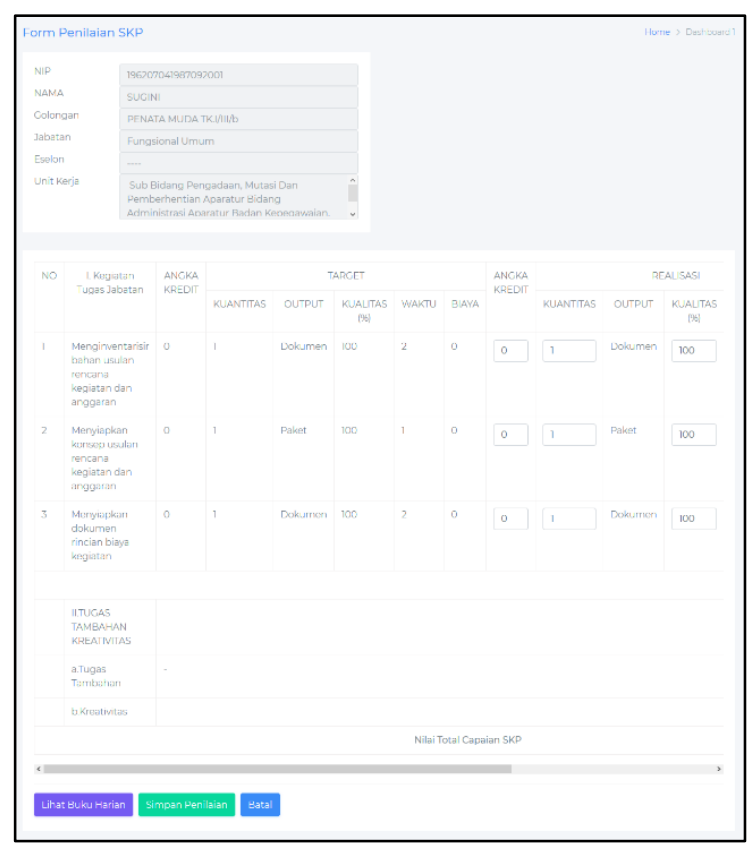

\section{Gambar 31. Form Penilaian}

d. Sistem secara otomatis akan mengeluarkan data realisasi dan nilai untuk kinerja pegawai. Akan tetapi, pejabat penilai dapat melakukan input realisasi manual yang sesuai dengan realisasinya.

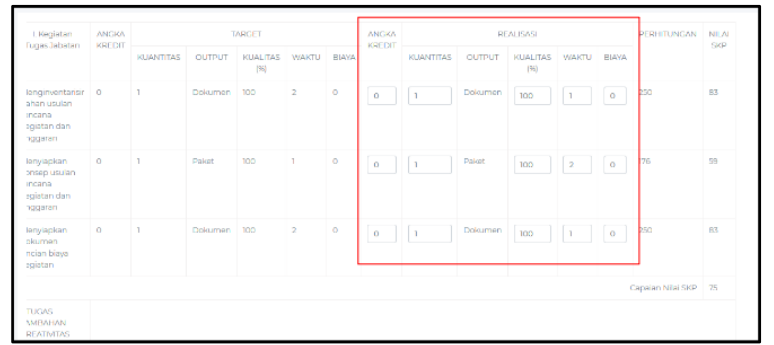

Gambar 32. Data Realisasi dan Nilai Kinerja Pegawai

e. Setelah selesai, simpan data dengan menekan tombol Simpan Penilaian.

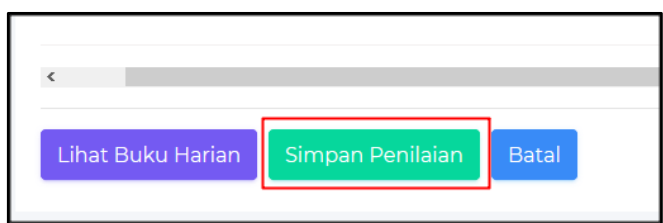

Gambar 33. Simpan Data Penilaian 
f. Status akan berubah menjadi "Sudah Dinilai":

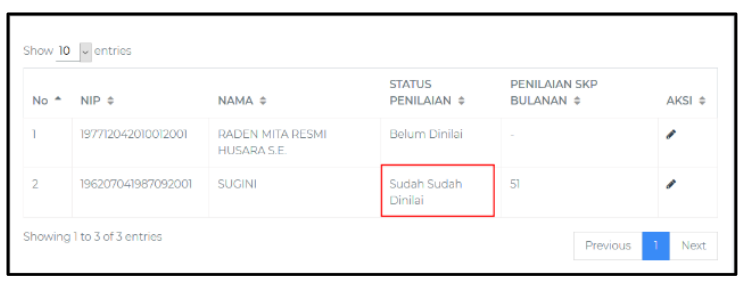

Gambar 34. Status Sudah Dinilai

\section{KESIMPULAN}

Merujuk pada hasil implementasi ada beberapa kesimpulan yang didapat dari kegiatan rancang bangun aplikasi e-kinerja:

1. SKP disusun setiap awal tahun oleh masingmasing pegawai. SKP tahunan ini dibreakdown ke dalam SKP bulanan;

2. Penilaian bulanan pegawai dilakukan berdasarkan pada input buku harian yang dilakukan oleh para pegawai. Penilaian bulanan inilah yang akan menjadi dasar bagi penyusunan penilaian SKP tahunan;

3. Aplikasi e-kinerja yang bersifat online sangat tergantung pada kondisi jaringan internet yang ada di kantor-kantor SKPD. Gangguan pada jaringan internet akan secara otomatis mengganggu proses pengisian buku harian pegawai.

Output dari system e-kinerja dapat digunakan sebagai input system remunerasi pegawai. Ini dilakukan untuk menjamin pemberian tunjangan yang adil bagi pegawai

\section{PUSTAKA}

Republik Indonesia, Peraturan Pemerintah No. 46 Tahun 2011 mengenai penilaian prestasi kerja pegawai negeri sipil.

Republik Indonesia, Peraturan Pemerintah No. 30 tahun 2019 tentang penilaian kinerja pegawai negeri sipil.

Republik Indonesia, Undang-undang No. 5 tahun 2014 mengenai Aparatur Sipil Negara (ASN).

Silberschatz, Abraham, Henry F. Korth, S. Sudarshan. 2006. Database System Concepts, New York: Mc Graw-Hill Book Company.

Sussi. 2011. Desain Sistem Simulator Ekskavator dengan Pendekatan Berorientasi Obyek Menggunakan UML, Tesis Magister, Bandung: Pasca Sarjana Institut Teknologi Bandung.

Wellington, Luke, Laura Thomson. 2017. PHP and MySQL Web Development, New York: Addison Wesley.

Whitten, Jeffrey L., Lonnie D. Bentley, Kevin C. 2001. Dittman, System Analysis and Design
Methods, international edition, New York: Mc Graw-Hill Book Company. 